\title{
Floristic study of bryophytes in a subtropical forest of Nabeup-ri at Aewol Gotjawal, Jejudo Island
}

\author{
Eun-Young YIM* and Hwa-Ja HYUN \\ Warm Temperate and Subtropical Forest Research Center, National Institute of Forest Science, Seogwipo 63582, Korea \\ (Received 24 February 2018; Revised 26 March 2018; Accepted 29 March 2018)
}

\begin{abstract}
This study presents a survey of bryophytes in a subtropical forest of Nabeup-ri, known as Geumsan Park, located at Aewol Gotjawal in the northwestern part of Jejudo Island, Korea. A total of 63 taxa belonging to Bryophyta (22 families 37 genera 44 species), Marchantiophyta (7 families 11 genera 18 species), and Anthocerotophyta ( 1 family 1 genus 1 species) were determined, and the liverwort index was $30.2 \%$. The predominant life form was the mat form. The rates of bryophytes dominating in mesic to hygric sites were higher than the bryophytes mainly observed in xeric habitats. These values indicate that such forests are widespread in this study area. Moreover, the rock was the substrate type, which plays a major role in providing micro-habitats for bryophytes. We suggest that more detailed studies of the bryophyte flora should be conducted on a regional scale to provide basic data for selecting indicator species of Gotjawal and evergreen broad-leaved forests on Jejudo Island.
\end{abstract}

Keywords: bryophyte, Aewol Gotjawal, liverwort index, life-form

Jejudo Island was formed by volcanic activities and has unique topological and geological features. In this unique volcanic terrain, forests established on lava flows are scattered around the island, known as "Gotjawal," which is a newly coined compound word that comes from dialects spoken on Jejudo Island (Jeju Special Self-Governing Province, 2009; Yoon, 2014). It is difficult to access Gotjawal and use it for agricultural purposes, as the trees and vines are dense, rocks of various sizes are scattered randomly, and the depth of the soil is shallow in Gotjawal. Therefore, thus far it has only been used for grazing cattle, making charcoal or as a firewood source and is commonly recognized as useless land (Jeon et al., 2012; Jeong, 2012, 2015; Yoon, 2014). Recently, however, it has become known that Gotjawal is an area inhabited by various plants and animals where unique and various ecosystems are also sustained; the area serves as a natural waterway of the type necessary to create underground water, and it has high preservation value (Jeon et al., 2012; Kang et al., 2013; Yoon, 2014; Jeong, 2015). In addition, its cultural importance has also emerged. Therefore, scientific studies of Gotjawal have been conducted to examine geological, ecological, and cultural aspects (Jeong et al., 2013; Jeon et al., 2015). However, a floristic study of bryophytes has not been conducted, except for that at Dongbaek-dongsan of Seonheul Gotjawal by Yim et al. (2013).

The areal ranges and Gotjawal terrains have not yet been established (Jeon et al., 2015). According to Song (2000), Gotjawal can be divided into four major terrains, i.e., GujwaSeongsan, Jocheon-Hamdeok, Hangyeong-Andeok, and Aewol. Among them, the Aewol Gotjawal terrain ranges from the Nokome Oreum ( $833.8 \mathrm{~m}$ above sea level) to Nabeup-ri and the far eastern area ( $90 \mathrm{~m}$ above sea level) with a distance of $9.0 \mathrm{~km}$ (Song, 2003). This region, which is the highest place within Gotjawal, is the only place where the vertical vegetation ranges from the temperate forest to the subtropical forest, and it is an area of high biodiversity (Kim et al., 2009).

The subtropical forest of Nabeup-ri, which is located at the bottom of Aewol Gotjawal, is also known as Geumsan Park. The forest is the only remaining evergreen forest in Aewol Gotjawal and in the flatlands of the northwestern area of Jejudo Island. In addition, the original vegetation is highly conserved.

*Author for correspondence: curie580@korea.kr

Open Access http://e-kjpt.org, (C) 2018 the Korean Society of Plant Taxonomists. This is an open-access article distributed under the terms of the Creative Commons Attribution Non-Commercial License (http://creativecommons.org/licenses/by-nc/4.0) which permits unrestricted non-commercial use, distribution, and reproduction in any medium, provided the original work is properly cited. 


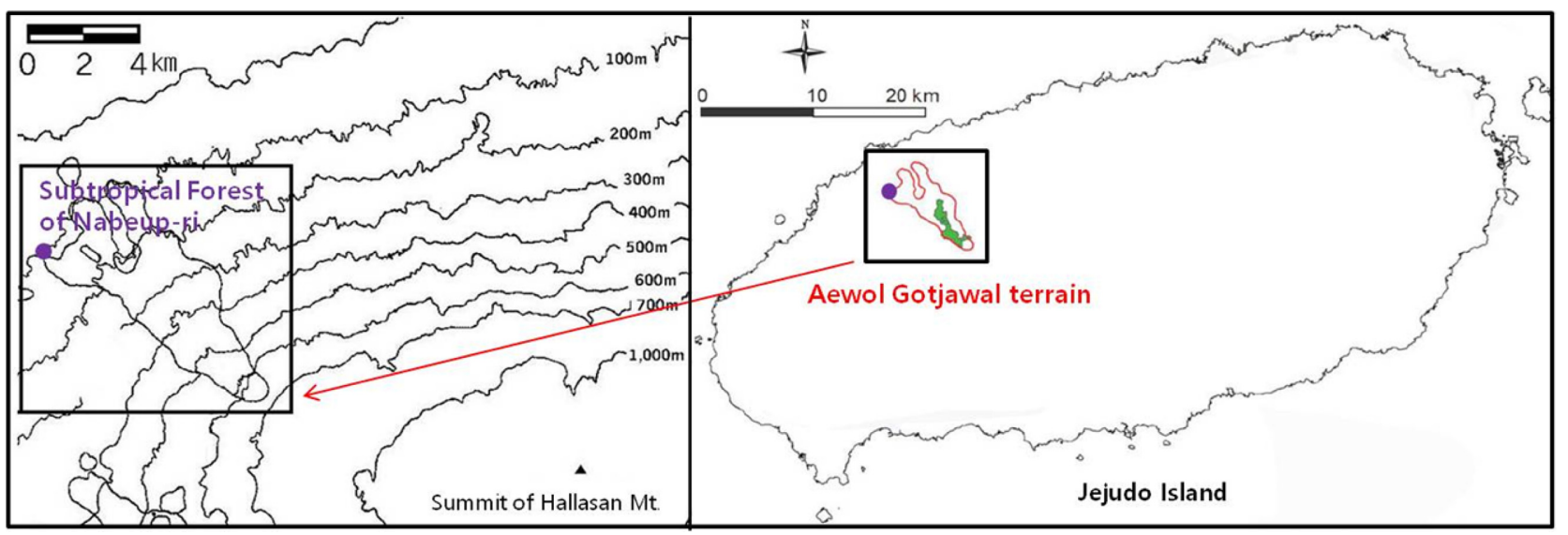

Fig. 1. The locations of the Aewol Gotjawal terrain and a subtropical forest of Nabeup-ri, Jejudo Island, Korea.

For these reasons, this area is considered to be a very important region from an academic point of view. Moreover, it is designated and protected as Natural Monument No. 375 by the Cultural Heritage Administration of Korea (The Cultural Property Preservation Bureau, Korea, 1993; Song et al., 2009). The flora and vegetation of vascular plants in this area have been well studied. It has been reported that a total of 123 taxa inhabit in this area, and the plant communities are divided into five groups: the Quercus glauca community, Machilus thunbergii community, Celtis sinensis community, Pinus thunbergii community and agricultural land (Boo et al., 2006; Song et al., 2009). However, as stated above, bryophytes have not been studied to date. Therefore, it is necessary to establish a comprehensive flora including bryophytes to provide basic data for the selection of indicator species.

The purpose of this study was to establish a comprehensive flora of the subtropical forest of Nabeup-ri. Furthermore, this study aims to contribute to studies of the bryophyte flora of Gotjawal and the evergreen broad-leaved forests on Jejudo Island on a regional scale and to provide basic data for selecting relevant indicator species.

\section{Materials and Methods}

\section{Study area}

Field surveys were carried out in Subtropical Forest of Nabeup-ri where the dense evergreen broad-leaved forest is distributed with an area of approximately $0.034 \mathrm{~km}^{2}$ (Fig. 1).

\section{Identification, nomenclature and arrangement of taxa}

The samples collected in the investigated area from July of 2011 to March of 2017 were identified at the species level by macroscopic morphology and microscopic features using relevant studies (Institute of Botany Chinese Academy of Sciences, 1972; Iwatsuki and Mizutani, 1972; Inoue, 1974, 1976, 1986; Choe, 1980; Noguchi, 1987, 1988, 1989, 1991, 1994; Hwang, 1991; Kim and Hwang, 1991; Gao et al., 1999; Makino, 2000; Iwatsuki, 2001; Li et al., 2001; Wu et al., 2002; Cao et al., 2003; Smith, 2004). The voucher specimens were deposited at the Warm-Temperate and Subtropical Forest Research Center in Korea (WTSFRC). Only one collection number for each taxon was cited to avoid repetition in the floristic list. The nomenclature and arrangement of the taxa follow the system proposed by Goffinet et al. (2009), Crandall-Stotler et al. (2009) and Renzaglia et al. (2008) for mosses, liverworts and hornworts, respectively.

\section{Life forms and substrates}

The life forms of bryophytes in the study area were estimated using work by Mägdefrau (1982), and they are also given in the floristic list for each taxon. The records of substrates for each taxon are included in this list.

\section{Number of bryophyte taxa and liverwort index}

We compared the number of taxa and the liverwort index of the subtropical forest of Nabeup-ri with those of other localities based on related studies [i.e., Deogyusan Mt. (Choi et al., 2010; Yoon et al., 2011), Taebaeksan Mt. (Papp, 2008), Gwanaksan Mt. (Hong, 1960a), Soyosan Mt. (Hong, 1960b), and Dongbaek-dongsan (Yim et al., 2013)]. The liverwort index, based on the finding that liverworts and hornworts tend to prefer more humid conditions than mosses, was calculated as follows (Nakanishi, 2001):

$$
\text { Liverwort index }(\%)=\frac{\text { No.of liverworts }+ \text { No.of hornworts }}{\text { The total No.of bryophytes }} \times 100
$$


Table 1. Comparison of the bryophyte species richness levels and liverwort indexes of the subtropical forest of Nabeup-ri and other localities.

\begin{tabular}{|c|c|c|c|}
\hline Locality & Area $\left(\mathrm{km}^{2}\right)$ & No. of species & Liverwort index \\
\hline \multicolumn{4}{|l|}{ Gotjawal area } \\
\hline Subtropical Forest of Nabeup-ri (Aewol Gotjawal) & 0.034 & 63 & 30.2 \\
\hline Dongbaek-dongsan (Seonheul Gotjawal) & 1.420 & 85 & 27.0 \\
\hline \multicolumn{4}{|l|}{ Mountain area } \\
\hline Deogyusan Mt. & 232.000 & 311 & 40.8 \\
\hline Taebaeksan Mt. & 17.440 & 144 & 29.2 \\
\hline Soyosan Mt. & 2.472 & 79 & 13.9 \\
\hline Gwanaksan Mt. & 19.220 & 78 & 17.9 \\
\hline
\end{tabular}

\section{Results and Discussion}

\section{Number of bryophyte taxa and liverwort index}

In this study, a total of 63 species belonging to Bryophyta (22 families 36 genera 44 species), Marchantiophyta ( 7 families 11 genera 18 species), and Anthocerotophyta (1 family 1 genus 1 species) were determined (Appendix 1). We expect that this study will provide the basic data for selecting indicator species of Gotjawal and the evergreen broad-leaved forests on Jejudo Island.

The results of a comparison of the number of taxa indicated that the subtropical forest of Nabeup-ri contained a rich diversity of bryophytes considering the area size (Table 1). Song et al. (2009) considered that the vascular flora of this area does not show high species richness. Nevertheless, this forest was evaluated as a well-conserved area based on a multicriteria evaluation Matrix (Song et al., 2009), as the area has been well managed by local residents due to cultural influences and has been designated and protected as the natural monument. We agree with the evaluation Song et al. (2009) and consider that the result for the number of taxa is related to the well-conserved forest.

The liverwort index is based on the finding that liverworts and hornworts tend to prefer more humid conditions than mosses. Therefore, it can be used to compare air humidity levels among different sites (Nakanishi, 2001). The liverwort index of the subtropical forest of Nabeup-ri was $30.2 \%$, a value that indicates that the air humidity of the investigated area was relatively low compared to that of Deogyusan Mt. but was higher than that of Taebaeksan Mt., Dongbaek-dongsan, Gwanaksan Mt., and Soyosan Mt. (Table 1). We also suggest that more detailed studies of the bryophyte flora of Korea should be conducted on the regional scale.

\section{Remarkable species}

The distributions of Philonotis turneriana (Schwägr.) Mitt. (큰물가이끼) and Homomallium connexum (Cardot) Broth. (쌍끝양털이끼) were newly recorded from Jejudo Island through this study. Species for which the distributions in Korea are not known (except for Jeju-do) thus far, Eurhynchium savatieri Schimp. ex Besch. (가는부리이끼), Taxiphyllum cuspidifolium (Cardot) Z. Iwats. (뾰족캬라잎이끼), and Plagiochila furcifolia Mitt. (비자날개이끼), were also found in this study area. However, it is difficult to recognize these bryophytes as endemic species on Jejudo Island and assess the rarity or conservation status of bryophytes in this study area because, in the case of Korea, bryophyte flora are unexplored and have been studied by few researchers, aiming mainly at Jejudo Island. Therefore, we suggest that comprehensive research on the bryophyte flora of Korea should be conducted continuously.

\section{Life forms}

We estimated the life form of each taxon in the study area, as presented in Fig. 2. The predominant life form was the mat form (25 species, 39.7\%) followed by the weft (17 species, $27 \%$ ), tall turf ( 9 species, 14.3\%), fan and cushion (4 species, $6.3 \%$ each), and short turf and tail ( 2 species, $3.2 \%$ each) forms. We analyzed the results based on the relationship between the adaptive strategy and life form of bryophytes according to Kürschner (2004), Uyar et al. (2007), and Glime (2017). As a result, the rate of pleurocarpous bryophytes (the mat, weft, fan, and tail life forms) dominating in mesic to hygric sites amounted to $76.2 \%$, whereas acrocarpous bryophytes (the tall turf, short turf, and cushion life forms), mainly observed in xeric habitats, amounted to $23.8 \%$ (Appendix 1, Fig. 2). These values indicate that such forests are widespread in the study area. 


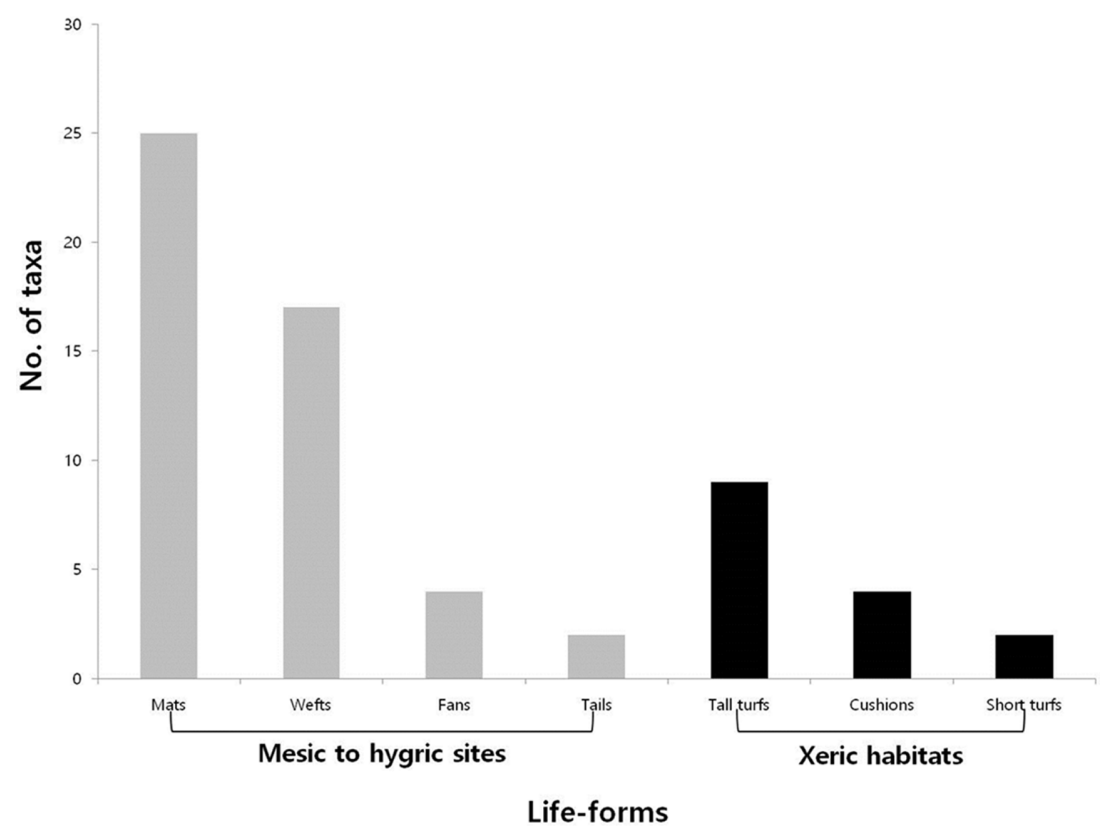

Fig. 2. Life form spectrum of the bryophytes in the study area.

Table 2. The numbers of taxa according to the substrate in the study area.

\begin{tabular}{lc}
\hline \hline \multicolumn{1}{c}{ Substrate } & No. of taxa \\
\hline Specific to only one substrate & 25 \\
L & 16 \\
$\mathrm{P}$ & 2 \\
$\mathrm{X}$ & 2 \\
$\mathrm{~S}$ & \\
Common to two or more substrates & 8 \\
L and P & 1 \\
L and S & 3 \\
L and X & 5 \\
L, P, and X & 1 \\
L, P, and S & 63 \\
\hline
\end{tabular}

L, epilithic; P, epiphytic; X, epixylous; S, on the soil.

It is meaningful that the rates of pleurocarpous bryophytes are higher in this area than in Dongbaek-dongsan (70.6\%), identical to the liverwort index (Yim et al., 2013). These values indicate that the subtropical forest of Nabeup-ri at Aewol Gotjawal is relatively more humid than Dongbaek-dongsan at Seonheul Gotjawal.

\section{Distribution pattern}

We estimated the substrates for each taxon to investigate the distribution pattern. The numbers of taxa according to the substrate are presented in Table 2. Upon an investigation of the substrates, the bryophytes on rocks were most diverse, at 40 taxa, followed by those on bark (33 taxa), decayed trees (10 taxa), and soil (4 taxa). The results appear to stem from the fact that volcanic rock masses of various sizes lay scattered over the study area, offering numerous micro-habitats for bryophytes due to one of the characteristics of Gotjawal: it is a place where rocks of various sizes are scattered randomly.

\section{Acknowledgments}

This study was supported by Research Fellowship Program of the National Institute of Forest Science in 2017. We wish to express our sincere thanks to two anonymous referees and the editorial boards of Korean Journal of Plant Taxonomy for their invaluable comments to improve the manuscript.

\section{Conflict of Interest}

Authors declare that there is no conflict of interest.

\section{Literature Cited}

Boo, Y. B., G. P. Song, M. O. Moon, H. J. Hyun, K. M. Song, E. Y. Yim and M. H. Kim. 2006. The Flora and vegetation of warm temperature forest in Nabeup-ri, Jeju. In Proceedings of Korean Forest Society Conference. Seoul National University, 
Seoul. Pp. 185-187. (in Korean)

Cao, T., C. Gao, X. Li, D. Zhang, H. Si and D. H. Vitt. 2003. Moss Flora of China, Vol. 3. Science Press, Beijing and Missouri Botanical Garden Press, St. Louis, MO, 141 pp.

Choe, D.-M. 1980. Illustrated Flora and Fauna of Korea. Vol. 24. Musci, Hepaticae. Ministry of Education, Seoul, 790 pp. (in Korean)

Choi S.-S., V. A. Bakalin and B.-Y. Sun. 2010. The liverwort flora of Mt. Deogyu (Korea). In Bryoflora of the Russian Far East: Taxonomy, Genesis, Phytogeographic Relations. Vladivostok. Pp. 24-25.

Crandall-Stotler, B., R. E. Stotler and D. G. Long. 2009. Phylogeny and classification of the Marchantiophyta. Edinburgh Journal of Botany 66: 155-198.

Gao, C., X. Li, T. Cao, B. Lin, D. H. Vitt and H. Si. 1999. Moss Flora of China, Vol. 1. Science Press, Beijing and Missouri Botanical Garden Press, St. Louis, MO, 273 pp.

Glime, J. M. 2017. Adaptive strategies: growth and life forms. Chapter 4-5. In Bryophyte Ecology. Vol. 1. 4-5-1 Physiological Ecology. Ebook sponsored by Michigan Technological University and the International Association of Bryologists. Retrieved Feb. 24, 2018, available from http://digitalcommons.mtu.edu/bryophyte-ecology/.

Goffinet, B., W. R. Buck and A. J. Shaw. 2009. Morphology, anatomy, and classification of the bryophyta. In Bryophyte Biology. 2nd ed. Goffinet, B. and A. J. Shaw (eds.), Cambridge University Press, Cambridge, NY. Pp. 55-138.

Hong, W. S. 1960a. The flora of bryophyte on Mt. Kwanak, with some new additions to the Korean flora. Journal of Plant Biology 3: 19-25.

Hong, W. S. 1960b. The flora of bryophyte on Mt. Soyo, with some new additions to the Korean flora. Journal of Plant Biology 3: 26-31. (in Korean)

Hwang, H. J. 1991. Sporic Plant of Joseon 9 (Bryophytes 2). Science Encyclopedia Synthetic Press, Pyeongyang, 391 pp. (in Korean)

Inoue, H. 1974. Illustrations of Japanese Hepaticae I. Tsukiji Shokan Publishing Co., Ltd., Tokyo, 189 pp. (in Japanese)

Inoue, H. 1976. Illustrations of Japanese Hepaticae II. Tsukiji Shokan Publishing Co., Ltd., Tokyo, 193 pp. (in Japanese)

Inoue, H. 1986. Field Guide for Bryophytes. Tokai University Press, Tokyo, 194 pp. (in Japanese)

Institute of Botany Chinese Academy of Sciences. 1972. Iconographia Cormophytorum Sinicorum 1. Science Press, Peking, 106 pp. (in Chinese)

Iwatsuki, Z. 2001. Mosses and Liverworts of Japan. Heibonsha Ltd., Tokyo, 355 pp. (in Japanese)

Iwatsuki, Z. and M. Mizutani. 1972. Colored Illustration of the
Bryophytes of Japan. Hoikusha, Osaka, 405 pp. (in Japanese) Jeju Special Self-Governing Province. 2009. Jeju Dialect Dictionary. Jeju, 730 pp. (in Korean)

Jeon Y. M., U. S. Ahn, C. G. Ryu, S. S. Kang and S. T. Song. 2012. A review of geological characteristics of Gotjawal terrain in Jeju Island: preliminary study. Journal of the Geological Society of Korea 48: 425-434. (in Korean)

Jeon Y. M., D. S. Kim, J. S. Ki and J. G. Koh. 2015. A proposal for geological classification of Gotjawal terrain in Jeju Island and its meaning. Journal of the Geological Society of Korea 51: 235-241. (in Korean)

Jeong, K.-J. 2012. A study on perception and use of Gotjawal in Jeju Island. Journal of the Association of Korean Photo-Geographers 22: 11-28. (in Korean)

Jeong, K.-J. 2015. The past, present and future of Gotjawal: questions and proposals about the existence of Gotjawal. Journal of the Association of Korean Photo-Geographers 25: 15-32. (in Korean)

Jeong, K.-J., S.-G. Kang, H.-S. Choi and C.-S. Kim. 2013. A study on charcoal production activities at Seonheul Gotzawal in Jeju Island. Journal of the Association of Korean Photo-Geographers 23: 37-55. (in Korean)

Kang, H. G., C. S. Kim and E. S. Kim. 2013. Human influence, regeneration, and conservation of the Gotjawal forests in Jeju Island, Korea. Journal of Marine and Island Cultures 2: 85-92.

Kim, D. S., S. H. Jeong, C. S. Kim, C. H. Shin and G. P. Song. 2009. Vegetation structure of Aeweol Gotjawal Terrain, Jejudo. In Proceedings of the 2009 General Meeting and Spring Conference of Plant Resources Society of Korea. Sangji University, Wonju, 84 pp. (in Korean)

Kim, Y. H. and H. J. Hwang. 1991. Sporic Plant of Joseon 8 (Bryophytes 1). Science Encyclopedia Synthetic Press, Pyeongyang, 222 pp. (in Korean)

Küschner, H. 2004. Life strategies and adaptations in bryophytes from the Near and Middle East. Turkish Journal of Botony 28: $73-84$.

Li, X., Z. Li, B. Lin, T. Cao, C. Gao, H. Si, D. G. Horton, Z. Iwatsuki, W. D. Reese and D. H. Vitt. 2001. Moss Flora of China 2. Science Press, Beijing and Missouri Botanical Garden Press, St. Louis, MO, 283 pp.

Mägdefrau, K. 1982. Life-forms of bryophytes. In Bryophyte Ecology. Smith, A. J. E. (ed.), Chapman and Hall, London. Pp. $45-58$.

Makino, T. 2000. Newly Revised Makino's New Illustrated Flora of Japan. The Hokuryukan Co. Ltd., Tokyo. Pp. 1173?1197. (in Japanese)

Nakanishi, K. 2001. Floristic diversity of bryophyte vegetation in relation to island area. The Journal of the Hattori Botanical 
Laboratory 91: 301-316.

Noguchi, A. 1987. Illustrated Moss Flora of Japan 1. Daigaku Printing Co., Ltd., Hiroshima. Pp. 2-242.

Noguchi, A. 1988. Illustrated Moss Flora of Japan 2. Daigaku Printing Co., Ltd., Hiroshima. Pp. 243-491.

Noguchi, A. 1989. Illustrated Moss Flora of Japan 3. Daigaku Printing Co., Ltd., Hiroshima. Pp. 493-742.

Noguchi, A. 1991. Illustrated Moss Flora of Japan 4. Daigaku Printing Co., Ltd., Hiroshima. Pp. 743-1012.

Noguchi, A. 1994. Illustrated Moss Flora of Japan 5. Daigaku Printing Co., Ltd., Hiroshima. Pp. 1013-1253.

Papp, B. 2008. Contributions to the bryophyte flora of the Mt. Taebaek, South Korea. Studia Botanica Hungarica 39: 89-100.

Renzaglia, K. S., J. C. Villarreal and R. J. Duff. 2008. New insights into morphology, anatomy, and systematics of hornworts. In Bryophyte Biology. 2nd ed. Goffinet, B. and A. J. Shaw (eds.), Cambridge University Press, Cambridge, NY. Pp. 139-171.

Smith, A. J. E. 2004. The moss flora of Britain and Ireland. 2nd ed. Cambridge University Press, Cambridge, 1012 pp.

Song, G. P., Y. B. Boo, H. J. Hyun, K. M. Song, C. H. Kang, Y. J. Kim, E. Y. Yim and M. H. Kim. 2009. The flora and vegetation of Nabeup Warm Temperature Forest Zone in Nab-eup city in Jeju. Journal of Ecocity 33: 129-136.

Song, S. T. 2000. Distribution and lithology of the Aa rubble flows in Cheju Island, Korea. PhD dissertation, Pusan National University, Busan, 118 pp. (in Korean)

Song, S. T. 2003. Lavas in Gotjawal terrain, Jejudo Island: No. 2. Aewol Gotjawal terrain. Baeknoknonchong, College of Education, Jeju National University 5: 253-263. (in Korean)

The Cultural Property Preservation Bureau, Korea. 1993. Overview of Korean Cultural Heritage: 1. Natural Monument. The Cultural Property Preservation Bureau, Korea, Seoul, p. 223. (in Korean)

Uyar, G., M. Alatas, M. Oren and T. Kecell. 2007. The bryophyte flora of Yenice Forests (Karabük, Turkey). International Journal of Botany 3: 129-146.

Wu, P., B. Lin, C. Gao, T. Cao, Z. Li, B. C. Tan, H. Si, Y. Jia, M. Wang, X. Fu, J. Sun and B. Zhong. 2002. Moss Flora of China, Vol. 6. Science Press, Beijing and Missouri Botanical Garden Press, St. Louis, MO, 221 pp.

Yim, E.-Y., M.-O. Moon, B.-Y. Sun and K. Nakanishi. 2013. Floristics of bryophytes in Dongbaek-dongsan at Seonheul Gotjawal. Korean Journal of Plant Taxonomy 43: 274-284.

Yoon, Y. J., C. H. Kim, K. V. Gorobets and B.-Y. Sun. 2011. The moss flora of Mt. Deogyu in Korea. Korean Journal of Plant Taxonomy 41: 287-297.

Yoon, Y. T. 2014. A humanities reflection on Got, Jawal and Gotjawal forest. Journal of Cheju Studies 41: 27-59. (in Korean) 
Appendix 1. Floristic list of Subtropical Forest of Nabeup-ri in Korea.

\begin{tabular}{|c|c|c|c|c|}
\hline Taxa & Korean name & Life-form & Substrate & $\begin{array}{c}\text { Voucher No. } \\
\text { (Eun-Young Yim-) }\end{array}$ \\
\hline \multicolumn{5}{|l|}{ Bryophyta Schimp. 선류식물문 } \\
\hline \multicolumn{5}{|l|}{ Polytrichaceae Schwägr. 솔이끼과 } \\
\hline Atrichum rhystophyllum (Müll. Hal.) Paris & 아기주름솔이끼 & Tall turfs & $\mathrm{S}$ & GSP073 \\
\hline \multicolumn{5}{|l|}{ Grimmiaceae Arn. 고깔바위이끼과 } \\
\hline Grimmia pilifera P. Beauv. & 흰털고깔바위이끼 & Cushions & $\mathrm{L}$ & GSP084 \\
\hline Schistidium apocarpum (Hedw.) Bruch \& Schimp. & 고깔바위이끼 & Cushions & $\mathrm{L}$ & GSP099 \\
\hline \multicolumn{5}{|l|}{ Ptychomitriaceae Schimp. 곱슬이끼과 } \\
\hline Ptychomitrium sinense (Mitt.) A. Jaeger & 곱슬이끼 & Cushions & $\mathrm{L}$ & GSP012 \\
\hline \multicolumn{5}{|l|}{ Fissidentaceae Schimp. 봉황이끼과 } \\
\hline Fissidens bryoides Hedw. & 꼬마봉황이끼 & Tall turfs & $\mathrm{L}$ & GSP008 \\
\hline \multicolumn{5}{|l|}{ Rhabdoweisiaceae Limpr. 주름꼬마이끼과 } \\
\hline Glyphomitrium humillimum (Mitt.) Cardot & 깍지이끼 & Cushions & $\mathrm{L}$ & GSP460 \\
\hline \multicolumn{5}{|l|}{ Erpodiaceae Broth. 나무연지이끼과 } \\
\hline Aulacopilum japonicum Broth. ex Cardot & 겉주름이끼 & Mats & $\mathrm{PX}$ & GSP138 \\
\hline Venturiella sinensis (Venturi) Müll. Hal. & 나무연지이끼 & Mats & $\mathrm{P}$ & GSP149 \\
\hline \multicolumn{5}{|l|}{ Dicranaceae Schimp. 꼬리이끼과 } \\
\hline Dicranella heteromalla (Hedw.) Schimp. & 억새이끼 & Tall turfs & $\mathrm{L}$ & GSP453 \\
\hline \multicolumn{5}{|l|}{ Pottiaceae Hampe 침꼬마이끼과 } \\
\hline Weissia controversa Hedw. & 꼬마이끼 & Short turfs & $\mathrm{S}$ & GSP104 \\
\hline \multicolumn{5}{|l|}{ Bryaceae Schwägr. 참이끼과 } \\
\hline Brachymenium nepalense Hook. & 노란참외이끼 & Short turfs & $P$ & GSP077 \\
\hline \multicolumn{5}{|l|}{ Mniaceae Schwägr. 초롱이끼과 } \\
\hline Trachycystis microphylla (Dozy \& Molk.) Lindb. & 아기초롱이끼 & Tall turfs & $\mathrm{P}$ & GSP013 \\
\hline \multicolumn{5}{|l|}{ Bartramiaceae Schwägr. 구슬이끼과 } \\
\hline Philonotis turneriana (Schwägr.) Mitt. & 큰물가이끼 & Tall turfs & $\mathrm{L}$ & GSP095 \\
\hline \multicolumn{5}{|l|}{ Hedwigiaceae Schimp. 톳이끼과 } \\
\hline Hedwigia ciliata (Hedw.) P. Beauv. & 톳이끼 & Tall turfs & $\mathrm{L}$ & GSP088 \\
\hline \multicolumn{5}{|l|}{ Leskeaceae Schimp. 고깔검정이끼과 } \\
\hline Haplocladium angustifolium (Hampe \& Müll. Hal.) Broth. & 침작은명주실이끼 & Wefts & LPX & GSP001 \\
\hline Haplocladium microphyllum (Hedw.) Broth. & 작은명주실이끼 & Wefts & $\mathrm{P}$ & GSP450 \\
\hline Leskea polycarpa Hedw. & 고깔검정이끼 & Wefts & $\mathrm{L}$ & GSP079 \\
\hline \multicolumn{5}{|l|}{ Thuidiaceae Schimp. 깃털이끼과 } \\
\hline Pelekium versicolor (Hornsch. ex Müll. Hal.) Touw & 아기깃털이끼 & Wefts & $\mathrm{P}$ & GSP215 \\
\hline \multicolumn{5}{|l|}{ Brachytheciaceae Schimp. 양털이끼과 } \\
\hline Brachythecium plumosum (Hedw.) Schimp. & 날개양털이끼 & Wefts & LP & GSP123 \\
\hline Brachythecium populeum (Hedw.) Schimp. & 양털이끼 & Wefts & LS & GSP043 \\
\hline Bryhnia novae-angliae (Sull. \& Lesq.) Grout & 세모양털이끼 & Wefts & $\mathrm{L}$ & GSP035 \\
\hline Eurhynchium hians (Hedw.) Sande Lac. & 물가침부리이끼 & Wefts & $\mathrm{L}$ & GSP355 \\
\hline Eurhynchium savatieri Schimp. ex Besch. & 가는부리이끼 & Wefts & LPX & GSP134 \\
\hline
\end{tabular}


Table 1. Continued.

\begin{tabular}{|c|c|c|c|c|}
\hline Taxa & Korean name & Life-form & Substrate & $\begin{array}{c}\text { Voucher No. } \\
\text { (Eun-Young Yim-) }\end{array}$ \\
\hline Rhynchostegium pallidifolium (Mitt.) A. Jaeger & 아기양털부리이끼 & Wefts & LPX & GSP016 \\
\hline \multicolumn{5}{|l|}{ Hypnaceae Schimp. 털깃털이끼과 } \\
\hline Callicladium haldanianum (Grev.) H. A. Crum & 풀이끼 & Wefts & PX & GSP148 \\
\hline Homomallium connexum (Cardot) Broth. & 쌍끝양털이끼 & Wefts & PX & GSP092 \\
\hline Homomallium japonicoadnatum (Broth.) Broth. & 들쌍끝양털이끼 & Wefts & $\mathrm{P}$ & GSP078 \\
\hline Pseudotaxiphyllum pohliaecarpum (Sull. \& Lesq.) Z. Iwats. & 빨간겉주목이끼 & Mats & $\mathrm{L}$ & GSP117 \\
\hline Taxiphyllum aomoriense (Besch.) Z. Iwats. & 겹친주목이끼 & Mats & $\mathrm{L}$ & GSP002 \\
\hline Taxiphyllum cuspidifolium (Cardot) Z. Iwats. & 뾰족캬라잎이끼 & Mats & LP & GSP122 \\
\hline Taxiphyllum taxirameum (Mitt.) M. Fleisch. & 주목이끼 & Mats & $\mathrm{L}$ & GSP005 \\
\hline \multicolumn{5}{|l|}{ Plagiotheciaceae M. Fleisch. 산주목이끼과 } \\
\hline Plagiothecium nemorale (Mitt.) A. Jaeger & 산주목이끼 & Mats & $P$ & GSP029 \\
\hline \multicolumn{5}{|l|}{ Entodontaceae Kindb. 윤이끼과 } \\
\hline Entodon sullivantii (Müll. Hal.) Lindb. & 가는윤이끼 & Wefts & $\mathrm{L}$ & GSP017 \\
\hline \multicolumn{5}{|l|}{ Pylaisiadelphaceae Goffinet \& W. R. Buck. 무성아실이끼과 } \\
\hline Pylaisiadelpha tenuirostris (Bruch \& Schimp. ex Sull.) W. R. Buck & 무성아실이끼 & Mats & $\mathrm{P}$ & GSP025 \\
\hline \multicolumn{5}{|l|}{ Sematophyllaceae Broth. 나무실이끼과 } \\
\hline Sematophyllum subhumile (Müll. Hal.) M. Fleisch. & 나무실이끼 & Mats & LP & GSP052 \\
\hline \multicolumn{5}{|l|}{ Neckeraceae Schimp. 납작이끼과 } \\
\hline Homalia trichomanoides (Hedw.) Schimp. & 윤납작이끼 & Fans & LP & GSP032 \\
\hline Neckera pusilla Mitt. & 윤아기납작이끼 & Fans & $\mathrm{P}$ & GSP028 \\
\hline Neckeropsis nitidula (Mitt.) M. Fleisch. & 리본납작이끼 & Fans & $\mathrm{L}$ & GSP094 \\
\hline Thamnobryum plicatulum (Sande Lac.) Z. Iwats. & 대호꼬리이끼 & Fans & $\mathrm{L}$ & GSP031 \\
\hline \multicolumn{5}{|l|}{ Anomodontaceae Kindb. 명주실이끼과 } \\
\hline Anomodon minor (Hedw.) Lindb. & 푸른명주실이끼 & Tails & $\mathrm{P}$ & GSP209 \\
\hline Haplohymenium longinerve (Broth.) Broth. & 긴줄바위실이끼 & Wefts & $\mathrm{X}$ & GSP391 \\
\hline Haplohymenium pseudotriste (Müll. Hal.) Broth. & 꼬마바위실이끼 & Wefts & LPX & GSP004 \\
\hline Haplohymenium triste (Ces.) Kindb. & 바위실이끼 & Wefts & $\mathrm{P}$ & GSP087 \\
\hline Herpetineuron toccoae (Sull. \& Lesq.) Cardot & 나선이끼 & Tails & LP & GSP011 \\
\hline \multicolumn{5}{|l|}{ Marchantiophyta Stotler \& Crand. -Stotl. 태류식물문 } \\
\hline \multicolumn{5}{|l|}{ Conocephalaceae Müll. Frib. ex Grolle 패랭이우산이끼과 } \\
\hline Conocephalum conicum (L.) Dumort. & 패랭이우산이끼 & Mats & $\mathrm{L}$ & GSP080 \\
\hline \multicolumn{5}{|l|}{ Metzgeriaceae H. Klinggr. 리본이끼과 } \\
\hline Metzgeria lindbergii Schiffn. & 리본이끼 & Mats & $\mathrm{L}$ & GSP036 \\
\hline \multicolumn{5}{|l|}{ Radulaceae Müll. Frib. 부채이끼과 } \\
\hline Radula japonica Gottsche ex Steph. & 부채이끼 & Mats & $\mathrm{P}$ & GSP112 \\
\hline Radula oyamensis Steph. & 처녀부채이끼 & Mats & LP & GSP173 \\
\hline \multicolumn{5}{|l|}{ Frullaniaceae Lorch 지네이끼과 } \\
\hline Frullania ericoides (Nees) Mont. & 초록지네이끼 & Mats & LP & GSP020 \\
\hline Frullania inflata Gottsche & 물가지네이끼 & Mats & $\mathrm{X}$ & GSP163 \\
\hline
\end{tabular}


Table 1. Continued.

\begin{tabular}{|c|c|c|c|c|}
\hline Taxa & Korean name & Life-form & Substrate & $\begin{array}{c}\text { Voucher No. } \\
\text { (Eun-Young Yim-) }\end{array}$ \\
\hline Frullania muscicola Steph. & 참지네이끼 & Mats & LP & GSP083 \\
\hline \multicolumn{5}{|l|}{ Lejeuneaceae Cavers 작은귀이끼과 } \\
\hline Acrolejeunea pusilla (Steph.) Grolle \& Gradst. & 사슴주름이끼 & Mats & $\mathrm{P}$ & GSP311 \\
\hline Cololejeunea japonica (Schiffn.) Mizut. & 세모귀이끼 & Mats & $\mathrm{P}$ & GSP003 \\
\hline Lejeunea japonica Mitt. & 작은귀이끼 & Mats & $\mathrm{L}$ & GSP069 \\
\hline Trocholejeunea sandvicensis (Gottsche) Mizut. & 둥근귀이끼 & Mats & LPX & GSP010 \\
\hline \multicolumn{5}{|c|}{ Lophocoleaceae Müll. Frib. ex Vanden Berghen 두끝벼슬이끼과 } \\
\hline Heteroscyphus argutus (Nees) Schiffn. & 아기비늘이끼 & Mats & $\mathrm{L}$ & GSP237 \\
\hline Heteroscyphus coalitus (Hook.) Schiffn. & 큰비늘이끼 & Mats & $\mathrm{P}$ & GSP268 \\
\hline Heteroscyphus planus (Mitt.) Schiffn. & 비늘이끼 & Mats & LPS & GSP033 \\
\hline Lophocolea minor Nees & 아기두끝벼슬이끼 & Mats & $\mathrm{L}$ & GSP023 \\
\hline \multicolumn{5}{|l|}{ Plagiochilaceae Müll. Frib. \& Herzog 날개이끼과 } \\
\hline Plagiochila furcifolia Mitt. & 비자날개이끼 & Tall turfs & $\mathrm{L}$ & GSP024 \\
\hline Plagiochila ovalifolia Mitt. & 둥근날개이끼 & Tall turfs & $\mathrm{L}$ & GSP331 \\
\hline Plagiochila sciophila Nees ex Lindenb. & 아기날개이끼 & Tall turfs & $\mathrm{L}$ & GSP118 \\
\hline \multicolumn{5}{|c|}{ Anthocerotophyta Rothm. ex Stotler \& Crand. -Stotler 각태류식물문 } \\
\hline \multicolumn{5}{|c|}{ Notothyladaceae (Milde) Müll. Frib. ex Prosk. 짧은뿔이끼과 } \\
\hline Phaeoceros carolinianus (Michx.) Prosk. & 마당뿔이끼 & Mats & $\mathrm{P}$ & GSP445 \\
\hline
\end{tabular}

L, epilithic; P, epiphytic; X, epixylous; S, on the soil. 